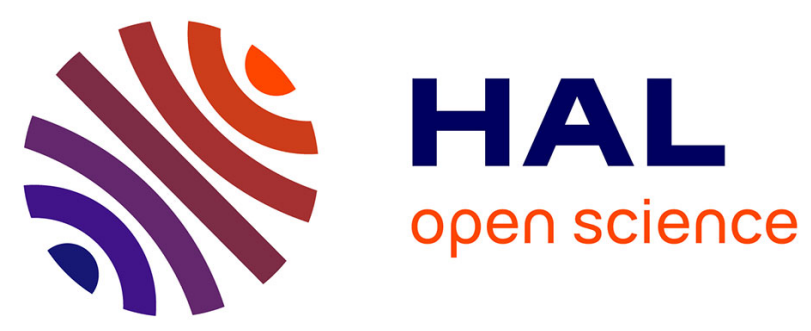

\title{
Intrahepatic long-term persistence of parvovirus B19 and its role in chronic viral hepatitis
}

\author{
Chun Wang, Albert Heim, Verena Schlaphoff, Pothakamuri Venkata \\ Suneetha, Kerstin Stegmann, Hong Jiang, Martin Krueger, Paraskevi Fytili, \\ Thomas F. Schulz, Markus Cornberg, et al.
}

\section{To cite this version:}

Chun Wang, Albert Heim, Verena Schlaphoff, Pothakamuri Venkata Suneetha, Kerstin Stegmann, et al.. Intrahepatic long-term persistence of parvovirus B19 and its role in chronic viral hepatitis. Journal of Medical Virology, 2009, 81 (12), pp.2079. 10.1002/jmv.21638 . hal-00531828

\section{HAL Id: hal-00531828 https://hal.science/hal-00531828}

Submitted on 4 Nov 2010

HAL is a multi-disciplinary open access archive for the deposit and dissemination of scientific research documents, whether they are published or not. The documents may come from teaching and research institutions in France or abroad, or from public or private research centers.
L'archive ouverte pluridisciplinaire HAL, est destinée au dépôt et à la diffusion de documents scientifiques de niveau recherche, publiés ou non, émanant des établissements d'enseignement et de recherche français ou étrangers, des laboratoires publics ou privés. 


\section{Journal of Medical Virology}

WILEY

\section{Intrahepatic long-term persistence of parvovirus B19 and its role in chronic viral hepatitis}

\begin{tabular}{|c|c|}
\hline Journal: & Journal of Medical Virology \\
\hline Manuscript ID: & JMV-09-1347.R1 \\
\hline Wiley - Manuscript type: & Research Article \\
\hline $\begin{array}{r}\text { Date Submitted by the } \\
\text { Author: }\end{array}$ & 23-Jul-2009 \\
\hline Complete List of Authors: & $\begin{array}{l}\text { Wang, Chun; Hannover Medical School, Department of } \\
\text { Gastroenterology, Hepatology and Endocrinology } \\
\text { Heim, Albert; Hannover Medical School, Department of Virology } \\
\text { Schlaphoff, Verena; Hannover Medical School, Department of } \\
\text { Gastroenterology, Hepatology and Endocrinology } \\
\text { Suneetha, Pothakamuri; Hannover Medical School, Department of } \\
\text { Gastroenterology, Hepatology and Endocrinology } \\
\text { Stegmann, Kerstin; Hannover Medical School, Department of } \\
\text { Gastroenterology, Hepatology and Endocrinology } \\
\text { Jiang, Hong; Hannover Medical School, Department of } \\
\text { Gastroenterology, Hepatology and Endocrinology } \\
\text { Krueger, Martin; Hannover Medical School, Department of } \\
\text { Gastroenterology, Hepatology and Endocrinology } \\
\text { Fytili, Paraskevi; Hannover Medical School, Department of } \\
\text { Gastroenterology, Hepatology and Endocrinology } \\
\text { Schulz, Thomas; Hannover Medical School, Department of Virology } \\
\text { Cornberg, Markus; Hannover Medical School, Department of } \\
\text { Gastroenterology, Hepatology and Endocrinology } \\
\text { Kandolf, Reinhard; University of Tuebingen, Department of } \\
\text { Molecular Pathology } \\
\text { Manns, Michael; Hannover Medical School, Department of } \\
\text { Gastroenterology, Hepatology and Endocrinology } \\
\text { Bock, Thomas; University of Tuebingen, Department of Molecular } \\
\text { Pathology } \\
\text { Wedemeyer, Heiner; Hannover Medical School, Department of } \\
\text { Gastroenterology, Hepatology and Endocrinology }\end{array}$ \\
\hline Keywords: & $\begin{array}{l}\text { Parvovirus B19, Chronic Hepatitis C, Intrahepatic persistence, } \\
\text { Cellular immunity }\end{array}$ \\
\hline
\end{tabular}




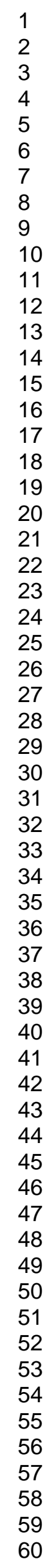

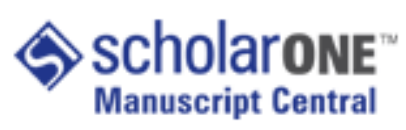

13

14

15

16

18

19

20

22

23

25

26

27

29

30

32

33

34

35

36

37

38

41

42

43

44

45
46

47

48

50

51

52

53

54

56

57

58

60

John Wiley \& Sons 
Medizinische Hochschule Hannover

MHH Gastroenterologie, Hepatologie, Endokrinologie Carl-Neuberg-Str. 130625 Hannover

Prof. Arie Zuckerman

Editor-in-Chief

Journal of Medical Virology
Dept of Gastroenterology, Hepatology and Endocrinology

Director: Prof. Dr. med. M. P. Manns

Priv. Doz. Dr. Heiner Wedemeyer

Viral Hepatitis - Immunology

Tel: $\quad 0511532-6814$

Fax: $\quad 0511532-8662$

Wedemeyer.Heiner@mh-hannover.de

Carl-Neuberg-Straße 1

D-30625 Hannover

Germany

23. Jul. 2009

Dear Prof. Zuckerman,

Thank you very much for considering a revised version of our manuscript on B19V-persistence in the liver of European patients. We thank the reviewers for the valuable comments which helped to improve the manuscript. All issues raised were addressed in the revised version. The manuscript was also re-edited by a native English speaker. We hope that this version is now acceptable for publication in the Journal of Medical Virology.

Kindest regards

Chun Wang

Heiner Wedemeyer

Priv. Doz. Dr. Heiner Wedemeyer

EASL Secretary General

Dept. of Gastroenterology, Hepatology and Endocrinology

Hannover Medical School

Carl-Neuberg Str. 1

30625 Hannover

Germany

Tel.: +495115326814

FAX: +495115328662

Email:Wedemeyer.Heiner@mh-hannover.de

http://www.mh-hannover.de/ag-wedemeyer.html

www.easl.ch

Forschungslabor

Tel.: 0511-532-4813

Forschungslabor - Büro

Tel.: 0511-532-2853
Leberambulanz

Tel. 0511-532 3006

Hepatitis-Studienambulanz

Tel.: 0511-532 3779
Hepatitis-Diagnostiklabor

Tel.: 0511-532 3004

Studienkoordination

Tel.: 0511-532 2730
Kompetenznetz Hepatitis

Tel.: 0511-532 6819

Resistenznetzwerk VirGil

Tel.: 0511-532 6814 
$\underline{\text { Point-to-point response: }}$

Reviewer 1

1. Can the authors explain why there is a difference in B19V DNA in the serum of Vietnamese vs German patients given the presence of B19V DNA in the livers of German patients? Was B19V DNA also present in the livers of the Vietnamese patients?

We thank the reviewer for this interesting question. Of note, B19V DNA detection in biopsy specimens is usually associated with persistence in the absence of circulating B19V DNA in sera or plasma (Norja, Simmonds et al., J Virol 2008). It also has to be considered that B19V genotype 1 is almost exclusively found in Western Europe while genotype 2 is frequent in Asia. This may also account for some differences. The previous study by Toan et al. (J Hepatol 2006) did not investigate B19V DNA in livers, however, other reports from Asia detected viral DNA in liver tissues from patients with fulminant hepatitis and biliary atresia (Abe K et al., Int J Med Sci 2007;4:105-9). We clarified this point in the discussion.

2. Did the breadth and strength of the CD4+ T cell responses to B19V correspond to the severity of liver disease?

$\mathrm{T}$ cell responses were tested in patients only in patients with mild liver disease (F score from 0-3, activity score from 2-7) and thus this interesting question cannot be answered.

3. Why was the CD8+ T cell response not assessed? This may not be essential for publication but might have been of interest.

The two MHC-class-II restricted peptides were selected based on previous studies (Kasprowicz V, et al. J Virol 2006;80:11209-17). As it was not our primary aim to perform a sophisticated and comprehensive analysis of B19V-specirfic T cell responses, we focused on published epitopes first. Moreover, few class-I B19V epitopes have been identified and there are restricted to a limited number of HLAs.

4. Why was the frequency of $\mathrm{HCV}$-specific CD4+ T cell response against NS3, NS4 and core proteins so low?

The frequency of HCV-specific $\mathrm{CD} 4{ }^{+} \mathrm{T}$ cell response was similar to most previous studies on patients with chronic HCV before therapy (e.g. Wedemeyer et al., JI 2002; Aberle et al., JID 2007).

5. Did the authors assess patients who cleared HCV spontaneously and who were B19V Ab positive for B19V and HCV- specific CD4+ T cell responses? Could the B19V have contributed to an increased clearance of HCV?

The author is raising an interesting point. However, no patients were included in this study who have cleared HCV spontaneously. Thus and unfortunately, the question if B19V could have contributed to an increased clearance of HCV remains speculative. To answer this question a much larger patient cohort would need to be investigated.

6. Is it possible to look at intrahepatic B19V specific CD4+ T cell responses? Could this explain why the virus is present in the liver but not in the serum?

Again, the reviewer is raising a very interesting question. These experiments are currently ongoing in our laboratory. However, at this stage data are inconclusive and thus we did not want to include them in this manuscript. A respective sentence has been added to the discussion.

7. Figures 2 and 3 present very similar data. The information contained in figure 3 is probably sufficient and figure 2 could be deleted.

Figure 2 shows that B19V DNA was detected more frequently in explanted livers than in routine biopsy samples while figure 3 presents the virus copy number in different cohorts. We think that this information is not identical and thus would like to keep both figures. However, if the editor feels that one of the two figures should be omitted we can delete one figure 


\section{Reviewer 2}

1.) Some of the numbers in the abstract need to be explained more clearly The numbers in the abstract have been clarified.

2.) The method of patient selection needs to be clarified - were these sequential patients or were there specific criteria for selection

The reviewer is addressing an important issue. The 91 patients with chronic hepatitis $\mathrm{C}$ were randomly recruited from our outpatient clinic. Before antiviral therapy, baseline sera were collected. Also the 16 patients studied for $\mathrm{T}$ cell responses were randomly selected, however, with concomitant liver carcinoma, autoimmune liver disease or other viral hepatitis were excluded.

3.) Morbus Wilson should be Wilson's Disease.

Has been changed.

4.) The number of $\mathrm{T}$ cell assays is too small for any definitive conclusions. The authors should state much DMSO was used in the T cell assays

We agree that $\mathrm{T}$ cell data are not conclusive yet and changed the discussion accordingly.

The DMSO was $0.5 \%$ which did not inhibit spontaneous proliferation of $\mathrm{T}$ cell according to our recent systematic study investigating the effect of peptide pools on effector functions of T cells. (Suneetha et al., J Immunol Methods 2009).

5). On P13 lines 254-6: The conclusion "Our findings clearly..." should be modified in view of the small sample size

We have made changes as suggested. 


\section{Tables}

Table 1. Characteristics between B19V IgG antibody positive and negative patients with chronic hepatitis $\mathrm{C}$

\begin{tabular}{|c|c|c|c|}
\hline & $\begin{array}{c}\text { B19V IgG pos } \\
(n=67)\end{array}$ & $\begin{array}{c}\text { B19V IgG neg } \\
(\mathrm{n}=24)\end{array}$ & $\mathrm{p}$ value \\
\hline $\begin{array}{l}\text { Age(years, mean } \pm S D \text {, } \\
\text { range:19-73) }\end{array}$ & $48.4 \pm 9.8$ & $43.9 \pm 8.7$ & 0.26 \\
\hline \multirow[t]{2}{*}{ Gender } & Male: 38 & Male: 12 & 0.50 \\
\hline & Female: 29 & Female: 12 & \\
\hline $\begin{array}{l}\text { F score (mean } \pm S D \text {, } \\
\text { range:0-6) }\end{array}$ & $2.6 \pm 2.1$ & $2.2 \pm 1.5$ & 0.34 \\
\hline $\begin{array}{l}\text { Percentage of live } \\
\text { cirrhosis }^{\mathrm{a}}(\%)\end{array}$ & 20.9 & 8.3 & 0.90 \\
\hline $\begin{array}{l}\text { Activity score(mean } \pm \mathrm{SD} \text {, } \\
\text { range:0-18) }\end{array}$ & $5.2 \pm 2.0$ & $5.2 \pm 2.2$ & 1.00 \\
\hline ALT ULN(times) & $3.1 \pm 2.3$ & $3.2 \pm 2.6$ & 0.92 \\
\hline AST ULN(times) & $2.4 \pm 1.8$ & $2.3 \pm 1.5$ & 0.71 \\
\hline gGT ULN(times) & $2.1 \pm 2.2$ & $2.2 \pm 2.8$ & 0.85 \\
\hline Total bilirubin(umol/l) & $12.2 \pm 7.9$ & $12.7 \pm 5.6$ & 0.74 \\
\hline Albumin $(\mathrm{g} / \mathrm{l})$ & $43.7 \pm 3.4$ & $44.9 \pm 3.1$ & 0.20 \\
\hline $\begin{array}{l}\text { Prothrombin time } \\
\text { (Quick value \%) }\end{array}$ & $98.4 \pm 22.5$ & $95.7 \pm 8.6$ & 0.43 \\
\hline Platelets(Tsd/ul) & $186.5 \pm 55.6$ & $187.3 \pm 93.4$ & 0.97 \\
\hline $\begin{array}{l}\text { Presence of B19V } \\
\text { viremia }\end{array}$ & 1 & 0 & 0.55 \\
\hline $\begin{array}{l}\text { Presence of anti-B19V } \\
\text { IgM }\end{array}$ & 1 & 0 & 0.55 \\
\hline
\end{tabular}

Legend: a, F score $>=5$.

There were no significant differences of clinic characteristics in these two groups. 
Table 2. Overview of $\mathrm{CD4}^{+} \mathrm{T}$ cells responses determined by CFSE assay of PBMCs in the presence or absence of antigen in B19V IgG antibody positive individuals.

\begin{tabular}{|c|c|c|c|c|c|}
\hline & VP1/2 4.7 & VP1/2 7.2 & HCV NS3 & HCV NS4 & Core \\
\hline \multicolumn{6}{|c|}{ B19V IgG antibody positve healthy individuals } \\
\hline HI 1 & - & - & NT & NT & NT \\
\hline HI 2 & - & - & NT & NT & NT \\
\hline HI 3 & - & - & NT & NT & NT \\
\hline HI 4 & - & - & NT & NT & NT \\
\hline HI 5 & - & - & NT & NT & NT \\
\hline HI 6 & - & - & NT & NT & NT \\
\hline HI 7 & - & $+(\mathrm{SI}=2.3 ; \Delta \mathrm{PF}=9)$ & NT & NT & NT \\
\hline HI 8 & - & - & NT & NT & NT \\
\hline HI 9 & - & - & NT & NT & NT \\
\hline HI 10 & - & - & NT & NT & NT \\
\hline HI 11 & - & - & NT & NT & NT \\
\hline HI 12 & - & - & NT & NT & NT \\
\hline HI 13 & - & - & NT & NT & NT \\
\hline HI 14 & - & $+(\mathrm{SI}=2.4 ; \Delta \mathrm{PF}=6.3)$ & NT & NT & NT \\
\hline HI 15 & - & - & NT & NT & NT \\
\hline HI 16 & - & - & NT & NT & NT \\
\hline HI 17 & - & $+(\mathrm{SI}=2 ; \Delta \mathrm{PF}=2.3)$ & NT & NT & NT \\
\hline HI 18 & - & - & NT & NT & NT \\
\hline HI 19 & - & - & NT & NT & NT \\
\hline \multicolumn{6}{|c|}{ B19V IgG antibody positive patients with chronic hepatitis C } \\
\hline HCV 1 & - & - & - & - & - \\
\hline HCV 2 & - & - & - & - & - \\
\hline HCV 3 & - & - & $+(\mathrm{SI}=3.6 ; \Delta \mathrm{PF}=1)$ & $+(\mathrm{SI}=5 ; \Delta \mathrm{PF}=1.5)$ & \\
\hline HCV 4 & - & - & - & - & - \\
\hline HCV 5 & - & - & - & - & - \\
\hline HCV 6 & $+(\mathrm{SI}=2.2 ; \Delta \mathrm{PF}=3.6)$ & $+(\mathrm{SI}=3.7 ; \Delta \mathrm{PF}=7.8)$ & - & $+(\mathrm{SI}=6.8 ; \Delta \mathrm{PF}=16)$ & \\
\hline HCV 7 & $+(\mathrm{SI}=2.6 ; \Delta \mathrm{PF}=1)$ & - & - & $+(\mathrm{SI}=6 ; \Delta \mathrm{PF}=3)$ & \\
\hline HCV 8 & - & - & - & - & - \\
\hline HCV 9 & - & $+(\mathrm{SI}=2.3 ; \Delta \mathrm{PF}=1.6)$ & $+(\mathrm{SI}=2.7 ; \Delta \mathrm{PF}=2)$ & $+(\mathrm{SI}=2.3 ; \Delta \mathrm{PF}=1.6)$ & \\
\hline HCV 10 & - & - & - & - & - \\
\hline HCV 11 & - & - & - & $+(\mathrm{SI}=2.6 ; \Delta \mathrm{PF}=1.5)$ & - \\
\hline HCV 12 & - & - & - & - & - \\
\hline HCV 13 & - & - & - & - & - \\
\hline
\end{tabular}

A positive response was considered if the $\Delta \mathrm{PF}$ was at least $1.0 \%$ and the stimulation index (SI) was >2.0. NT, not tested. 
Fig. 1. Fluctuation of ALT, HCV-RNA and B19V viremia in the patient with chronic hepatitis C. The patient was followed for 48 months and treated twice with interferon alpha and ribavirin. B19V viremia lasted at least one year even during the first combination therapy. The first combination therapy (from follow-up month 0 to 5) consisted of interferon alpha-2b plus ribavirin for 22 weeks. The dose of interferon alpha-2b was $10 \mathrm{MU}$ per day in the first two weeks followed by $3 \mathrm{MU}$ per day for 8 weeks followed by 3 MU every 2nd day. The second combination therapy (from follow-up month 13 to 19) consisted of PEG-interferon alpha-2b (100 $\mu \mathrm{g} \mathrm{qw)} \mathrm{plus} \mathrm{ribavirin} \mathrm{for} 20$ weeks. 
Fig. 2. Presence of B19V DNA in explanted livers and routine liver biopsy samples. B19V DNA was amplified more frequently in explanted end-stage liver tissues (74\%) than in biopsy samples $(44 \%)(p<0.05)$. The same trend was found in non-HCV subgroups (non-HCV explanted liver tissues vs non-HCV liver biopsy samples, $\mathrm{p}<0.05)$

$338 \times 220 \mathrm{~mm}(96 \times 96 \mathrm{DPI})$ 
1

2

3

4

5

6

7

8

9

10

11

12

13

14

15

16

17

18

19

20

21

22

23

24

25

26

27

28

29

30

31

32

33

34

35

36

37

38

39

40

41

42

43

44

45

46

47

48

49

50

51

52

53

54

55

56

57

58
59

60

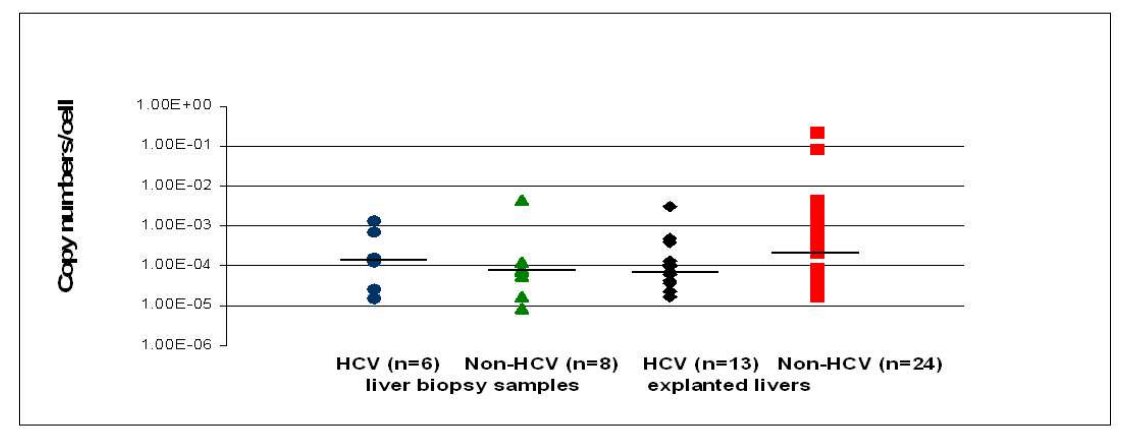

Fig. 3. B19V DNA copy numbers per cell in explanted livers and routine liver biopsy samples. The median of B19V DNA copy numbers/cell in routine liver biopsy samples was $8.29 \mathrm{E}-05$ (in chronic hepatitis C subgroup was 1.38E-04, while in non-HCV liver disease subgroup was 7.18E-05). The median of B19V DNA copy numbers/cell in explanted livers was 9.63E-05 (in end-stage hepatitis C subgroup was $6.95 \mathrm{E}-05$, while in non-HCV end-stage liver disease subgroup was 2.42E04). There was no significant difference of virus load in these groups.

$338 \times 172 \mathrm{~mm}(96 \times 96$ DPI $)$ 
Fig. 4. Proliferation of $C D 4+T$ cells in patients with chronic hepatitis $C$ and healthy individuals with serologically recovered B19V infection.

Dot plots show the flow cytometric analysis of the proportion of CD4+ T cells proliferating in response to stimulation of PBMCs with no stimulus (DMSO), phytohemagglutinin (PHA), tetanus (TT), two synthetic B19V peptides (VP1/2 4.7, VP1/2 7.2) in two different concentrations $(1 \mu \mathrm{g} / \mathrm{ml}$ and $5 \mu \mathrm{g} / \mathrm{ml}$ ) or recombinant HCV NS3, NS4 and core protein. Values in the upper left quadrants of dot plots represent the proportion of CFSElow CD4+ T cells (daughter cells), which have proliferated during the 7-day culture. Values in the upper right quandrants of dot plots are CFSEhigh CD4+ T cells (parent cells).

4A shows the positive responses of CD4+ T cells in a B19V IgG antibody positive patient with chronic hepatitis C after stimulation of PBMCs with VP1/2 4.7, VP1/2 7.2 and HCV NS4. $338 \times 259 \mathrm{~mm}(96 \times 96 \mathrm{DPI})$ 
Fig. 4B shows the negative responses of CD4+ T cells in a B19V IgG antibody positive patient with chronic hepatitis $C$ after stimulation of PBMCs with B19V peptides, while positive with HCV antigen (NS3 and NS4). 
Fig. 4C shows the positive responses of CD4+ T cells in a B19V IgG antibody positive healthy control after stimulation of PBMCs with VP1/2 7.2 $338 \times 187 \mathrm{~mm}(96 \times 96 \mathrm{DPI})$ 


\section{Intrahepatic long-term persistence of parvovirus B19 and its role in chronic viral hepatitis}

(1) Department of Gastroenterology, Hepatology and Endocrinology, Hannover Medical School, Germany

(2) Department of Virology, Hannover Medical School, Germany

(3) Department of Molecular Pathology, Institute of Pathology, University Hospital of Tuebingen, Germany

(4) Department of Endocrinology and Metabolism, Tongji University affiliated Tenth People's Hospital,, Shanghai, China

\section{Running title: Parvovirus B19 infection in hepatitis C}

* CTB and HW contributed equally to this work and thus shared last authorship

Address for correspondence:

Priv. Doz. Dr. Heiner Wedemeyer

Klinik für Gastroenterologie, Hepatologie und Endokrinologie

Medizinische Hochschule Hannover Carl-Neuberg Str. 1

30625 Hannover, Germany

Tel.: +495115326814

FAX.: +495115328662

Email: Wedemeyer.Heiner@mh-hannover.de 


\begin{abstract}
Parvovirus B19 (B19V) has been detected in the liver of Asian patients infected with HBV and may contribute to acute and chronic liver disease. This study aimed to investigate the impact of B19V infection in European patients with viral hepatitis. B19V DNA was detected in 1/91 and 0/50 serum samples from patients with chronic hepatitis $\mathrm{C}$ and $\mathrm{B}$, respectively. In contrast, B19V DNA was amplified frequently from explanted end-stage liver tissues $(37 / 50,74 \%)$ and from routine biopsy samples $(14 / 32,44 \%)(\mathrm{p}<0.05)$. However, there was no significant difference in B19V copy number per cell between these two groups. B19V-specific CD4+ T cell responses to two dominant MHC-class-restricted epitopes were detected in a similar frequency in healthy anti-B19V-positive individuals $(3 / 19 ; 16 \%)$ and patients with chronic hepatitis C $(3 / 13 ; 23 \%)$. These results indicate that B19V can persist in the liver. However, there is no evidence that B19V is a "hepatitis virus" worsening liver disease in European patients with chronic hepatitis C.
\end{abstract}

Keywords : Parvovirus B19; Chronic Hepatitis C; Intrahepatic persistence; Cellular immunity 


\section{Introduction}

2 Human parvovirus B19 (B19V) is a species of the genus Erythrovirus, family

3 Parvoviridae, which has been discovered by Cossart et al. [1975]during the measurement of

4 hepatitis B virus surface antigen in 1974. B19V is the causative agent for erythema 5 infectiosum, also termed fifth disease or "slapped-cheek" disease. In the past decade, a

6 growing number of studies have been published aiming to investigate a possible association

7 between B19V and liver diseases especially in the etiology of fulminant liver failure and the 8 persistence of B19V in the liver [Abe et al., 2007; Drago et al., 1999; Eis-Hubinger et al., 9 2001; He et al., 2003; Hillingso et al., 1998; Karetnyi et al., 1999; So et al., 2007; Sokal et al., 10 1998; Wong et al., 2003; Yoto et al., 1996]. Recently, B19V-infection has been linked with 11 severe liver disease in Vietnamese patients with chronic hepatitis B [Toan et al., 2006].

12 However, only few studies have investigated B19V in European patients and available 13 results are controversial. Thus the first aim was to investigate if B19V DNA can be detected 14 in the liver.

15 The hepatitis $\mathrm{C}$ virus (HCV) is the type species of the genus Hepacivirus, family 16 Flaviviridae. $\mathrm{HCV}$ is a major causative agent of liver cirrhosis and hepatocellular carcinoma.

17 Viral co-infection (e.g. HBV, HIV) is one major factor which influences the natural history 18 of HCV infection and contributes to the development of liver cirrhosis [Manns et al., 2006].

19 The prevalence of B19V co-infection in European patients with chronic hepatitis $\mathrm{C}$ in 20 different stages of liver damage is unknown. Based on the recent finding of B19V being 21 involved possibly in the disease progression of Asian patients infected with hepatitis $\mathrm{B}$, the 22 second aim was to investigate whether B19V infection is a co-factor for the disease 23 progression in chronic hepatitis $\mathrm{C}$.

24 Immune responses against $\mathrm{HCV}$ are crucial to control viral replication, elimination, as 25 well as the outcome of chronic infection [Rehermann and Nascimbeni, 2005]. Both innate 
26 and adaptive immune responses against a virus can be altered significantly by past or

27 ongoing exposure to third pathogens [Welsh et al., 2006]. For hepatitis C it has been

28 suggested that $\mathrm{T}$ cell cross-reactivity between $\mathrm{HCV}$ and the influenza A virus [Wedemeyer

29 et al., 2001] may cause subfulminant courses of acute HCV infection [Urbani et al., 2005].

30 However, $\mathrm{T}$ cell responses in coinfections with other pathogens than HIV have rarely been

31 investigated in patients with chronic hepatitis C. Thus, the third aim was to study the

32 frequency and strength of B19V-specific and $\mathrm{HCV}$-specific $\mathrm{T}$ cell responses in individuals

33 with persistent $\mathrm{HCV}$ infection. 
34 Patients and methods

\section{Patients infected with hepatitis C: sera and liver biopsy samples}

36 Stored baseline sera were studied from randomly selected 75 patients with chronic

37 hepatitis $\mathrm{C}$ infection who have been treated with interferon alpha and ribavirin combination

38 therapy. Another 16 sera and paired peripheral blood mononuclear cells (PBMCs) were

39 collected from patients with chronic hepatitis $\mathrm{C}$ infection without antiviral therapy for

40 evaluating cellular immune responses. For screening B19V DNA, 49 paraffin treated liver

41 biopsy samples out of these patients were also recruited. These 91 patients had a mean age

42 of 46 years ranging from 19-73 years (male: 49; female: 42). Characteristics are summarized

43 in Table 1. The presence of anti-HCV antibody (ELISA) and HCV RNA $>=600 \mathrm{IU} / \mathrm{ml}$ for

44 more than 6 months were required for the diagnosis of chronic HCV infection. Patients with

45 concomitant hepatocellular carcinoma, autoimmune liver disease or other viral hepatitis 46 were excluded.

\section{$47 \quad$ Patients infected with hepatitis B}

48 Serum samples were taken from 50 patients with chronic hepatitis B infection selected at 49 random (mean age: 47 years, range: 15-72; male: 33, female: 17). The presence of hepatitis 50 B surface antigen (HBsAg) for more than 6 months was required for the diagnosis of 51 chronic HBV infection.

52 All patients were treated in the outpatient clinic of the Department of Gastroenterology,

53 Hepatology and Endocrinology of Hannover Medical School, Germany.

\section{Liver tissue samples}

55 Explanted liver tissues were obtained at the time of liver transplantation from 50 patients 56 with end-stage liver damage undergoing orthotopic liver transplantation for various reasons 57 from 1993 to 2000 at the Hannover Medical School (mean age: 47 years, range: 8-69). Of 58 these, 19 had HCV related end-stage liver disease, while 31 had non-HCV liver cirrhosis 
59 (e.g. primary biliary cirrhosis, primary sclerosing cholangitis, Wilson's disease and

60 Polycystic liver disease). Another 32 liver biopsy samples were obtained from patients with

61 chronic liver disease (mean age: 46 years, range: 33-75). Of these, 13 had chronic hepatitis

62 C. All samples were stored at $-20^{\circ} \mathrm{C}$ until used.

\section{Healthy individuals}

64 Sera and paired PBMCs were collected from 30 healthy volunteers (mean age: 37.5 years,

65 range: 25-65; male: 16, female: 14). Among them, 19 were B19V-IgG antibody positive 66 while 11 were negative.

\section{Methods}

\section{Serological tests}

69 Anti-B19V IgM and anti-B19V IgG antibodies were tested using the Parvovirus B19 $70 \mathrm{IgM} / \mathrm{IgG}$ Enzyme Immunoassay (Biotrin, Dublin, Ireland) according to the manufacture's 71 instruction. Anti-HCV antibodies were tested using ARCHITECT Anti-HCV assay (Abbott, 72 Abbott Park, IL, USA).

73 Extraction of nucleic acids from liver tissue

74 DNAs were extracted from 20-30g frozen explanted liver tissue using the QIAamp DNA 75 mini kit (Qiagen, Hilden, Germany) according to the manufacture's instruction.

76 DNAs from paraffin treated liver samples was extracted as described previously 77 [Lehmann et al., 2007].

\section{Polymerase chain reaction (PCR)}

79 Quantitative real-time PCR (qPCR) was performed using the B19V artus LC-PCR kit

80 (Qiagen, Hilden, Germany) according to the manufacture's instruction. A qPCR of genomic

81 C-reactive protein (CRP) DNA was performed with same samples in order to determine the 82 amount of human CRP DNA representing the actual amount of amplifiable cellular DNA in 
83 each sample [Gan et al., 2002; Wandinger et al., 2000]. B19V copy numbers per cell were

84 calculated from the amplification of B19V divided by the amount of human CRP DNA.

85 Samples were defined as a "serologically recovered" cohort by the presence of anti-B19V

86 IgG with the absence of IgM and DNA.

87 Isolation of PBMCs and carboxy fluorescein succinimidyl ester (CFSE)-based T cell 88 proliferation assay

89 PBMCs were separated from heparinized blood samples by gradient centrifugation on

90 Ficoll-Paque and stored in liquid nitrogen until used.

91 CFSE-based $\mathrm{T}$ cell proliferation assay was performed as described previously

92 [Wedemeyer et al., 2002]. Briefly, frozen PBMCs were thawed and suspended at $10^{7} / \mathrm{ml}$ in 93 PBS plus $0.2 \%$ BSA and incubated at $37^{\circ} \mathrm{C}$ for 7 min with 2.5ųM CFSE (Sigma, St. Louis, 94 MO, USA). An equal volume of FCS was added thereafter and cells were incubated on ice 95 for $5 \mathrm{~min}$. to stop reaction, followed by 3 times washing. Then, labelled cells were 96 resuspended in medium (RPMI 1640 supplemented with 10\% inactive AB serum and 97 penicillin), plated at $0.3 * 10^{6}$ cells per $200 \mathrm{ul}$ per well in round-bottom 96 -well microtiter 98 plates and cultured with DMSO alone (background), synthetic peptides VP1/2 7.2 99 (LASEESAFYVLEHSSFQLLG) and VP1/2 4.7 (FLIPYDPEHHYKVFSPAASS) 100 [Kasprowicz et al., 2006] (ProImmune, Oxford, UK) at a final concentration of $1 \mu \mathrm{g} / \mathrm{ml}$ and $1015 \mu \mathrm{g} / \mathrm{ml}$, tetanus toxoid $(\mathrm{TT}, 3 \mu \mathrm{g} / \mathrm{ml})$ and PHA $(6 \mu \mathrm{g} / \mathrm{ml})$ as positive controls at $37^{\circ} \mathrm{C}$ with $1025 \% \mathrm{CO}_{2}$ for 7 days. Each condition was duplicated. DMSO concentration was $0.5 \%$ which 103 did not inhibit spontaneous proliferation of $\mathrm{T}$ cells according to the recent systematic study 104 investigating the effect of peptide pools on effector functions of T cells [Suneetha et al., 105 2009]. 
106 PBMCs from patients with chronic HCV infection were stimulated also with recombinant

107 genotype 1a-derived HCV core, NS3 and NS4 protein (Microgen, Munich, Germany) at a 108 final concentration of $1 \mu \mathrm{g} / \mathrm{ml}$.

109 Flow cytometric analysis: Flow cytometric data (100,000 nongated events) were acquired 110 on a BD FACS-Calibur 4-color flow cytometer using BD Cellquest software (both from BD 111 Biosciences, San Jose, CA, USA). For analysis, BD FlowJo 6.1.1 (Treestar, Ashland, OR, 112 USA) was used to gate on $\mathrm{CD}^{+} \mathrm{CD}^{+} \mathrm{T}$ cell populations. The background of $\mathrm{CD} 4^{+} \mathrm{T}$ cells 113 proliferative frequency (\%) was calculated as the number of $\mathrm{CFSE}^{\text {low }} \mathrm{CD}^{+} \mathrm{T}$ cells /(numbers 114 of $\mathrm{CFSE}^{\text {low }} \mathrm{CD}^{+} \mathrm{T}$ cells + numbers of $\mathrm{CFSE}^{\text {high }} \mathrm{CD}^{+} \mathrm{T}$ cells) $* 100$ in the absence of antigen.

115 The $\Delta \mathrm{PF}$ was calculated by subtracting the mean background proliferation from the 116 proliferating fraction in response to specific antigen. The SI was calculated by dividing the 117 antigen-induced PF by the background PF. Both a $\triangle \mathrm{PF}$ of $1.0 \%$ or more and an SI of 2.0 or 118 more are considered as a positive response, as previously defined [Crawford et al., 2004;

119 Semmo et al., 2007] .

120 The study was approved by the Institutional Review Board of the Hannover Medical

121 School, Germany.

122 Statistical analysis

123 Statistical analysis was performed using t-test and $\chi^{2}$ test with SPSS 10.0 software. 
124 Results

125 Prevalence of B19V antibodies and B19V DNA in serum samples from patients with 126 chronic hepatitis $\mathbf{C}$ and $B$ infection

127 Anti-B19V IgG antibodies were detected in 67/91 of patients with chronic hepatitis C $128(74 \%)$ and in 19/30 healthy individuals (63\%). Only one HCV sample was positive for 129 B19V IgM antibody. In contrast to previous studies on Asian patients infected with HBV 130 and HCV [Hsu et al., 2005; Toan et al., 2006], all but one HCV sera were negative for 131 B19V DNA by qPCR. Importantly, B19V DNA was also undetectable in all 50 sera 132 collected from HBsAg positive patients. Thus, B19V viremia is an extremely rare finding in 133 German patients with viral hepatitis B and C.

\section{Clinical characteristics in relation to B19V serology}

135 Clinical characteristics including age, sex, liver enzymes, albumin and bilirubin levels, 136 prothrombin time and platelets, as well as histological staging and inflammation scores did 137 not differ between B19V IgG antibody positive and negative subgroups as shown in Table 1. 138 Thus, past B19V infection had no apparent effect on the course of HCV infection in this 139 cross-sectional study.

\section{Interferon treatment of a patient with persistent B19V viremia}

141 The single B19V DNA positive serum sample tested also positive for both anti-B19V 142 IgM and IgG. Consecutive serum samples of the same patient were collected for up to 48 143 months. The B19V viremia lasted at least one year even when the patient received 144 combination therapy of daily injections with recombinant interferon alpha-2b plus ribavirin. 145 B19V viremia showed no obvious association with ALT levels or HCV viremia (Fig. 1). 146 However, the patient became B19V-negative during a second course of antiviral therapy 147 with pegylated interferon alpha-2b plus ribavirin. 
B19V DNA in liver biopsy samples and explanted livers

Because of the rare occurrence of B19V viremia, B19V DNA has been screened in paired

151 routine biopsy blocks from these patients. However, the amount of cells of these blocks was

152 very low, only 4 out of 49 were positive. Therefore additional liver tissues from biopsy

153 samples and explanted liver tissues were recruited for further study.

154 The presence of B19V DNA in the liver by qPCR is shown in figure 2. B19V DNA was 155 amplified from more than half of liver tissues which has been studied and detected more 156 frequently in explanted end-stage liver tissues $(37 / 50,74 \%)$ than in biopsy samples $(14 / 32$, $15744 \%)(\mathrm{p}<0.05)$. This held also true for non-HCV subgroups (non-HCV explanted liver 158 tissues vs non-HCV liver biopsy samples, $\mathrm{p}<0.05)$.

159 In biopsy samples, the presence of B19V DNA was similar in severe liver disease (F 160 score $>=5$ ) as in moderate liver disease $(F$ score $<5)$. In the same group, there was no 161 difference of grading (inflammatory activity) in B19V DNA positive samples versus 162 negative samples.

163 While the frequency of B19V DNA-positive tissues differed between explanted liver 164 tissues and routine biopsy samples, there was no significant difference of virus copy number 165 per cell between explanted liver tissues and routine biopsy samples, as well as HCV-positive 166 versus HCV-negative liver samples (Fig. 3).

168 Proliferation of $\mathbf{B 1 9 V}$-specific $\mathrm{CD4}^{+} \mathbf{T}$ cells in patients with chronic hepatitis $\mathrm{C}$ and 169 healthy individuals with B19V recovered serologically

170 A flow cytometry-CFSE assay was performed to evaluate the proliferation of 171 B19V-specific CD4 ${ }^{+} \mathrm{T}$ cell after stimulation of PBMCs with synthetic peptides. In B19V 172 serologically recovered healthy individuals, $3 / 19(16 \%)$ showed a positive $\mathrm{CD}^{+} \mathrm{T}$ cell 173 responses to the peptide VP1/2 7.2. In anti-B19V IgG positive patients with chronic 
174 hepatitis $\mathrm{C}, 3 / 13$ (23\%) patients had a positive response to the peptide VP1/2 7.2 and/or the

175 peptide 4.7. Representative examples of three individuals are shown in figure 4.

$176 \mathrm{HCV}$-specific $\mathrm{CD}^{+} \mathrm{T}^{\mathrm{T}}$ cells against NS3, NS4 and core proteins were detectable in 2/13,

$1775 / 13$ and $0 / 13$ patients with chronic hepatitis $\mathrm{C}$, respectively. The summary of CD4 ${ }^{+} \mathrm{T}$ cell 178 responses after stimulating with specific antigens is shown in Table 2. 


\section{Discussion}

$180 \mathrm{~B} 19 \mathrm{~V}$ is the causative agent of erythema infectiosum (fifth disease) [Anderson et al.,1983;

181 1985]. The presence of anti-B19V IgG antibody increases with age, $2-15 \%$ in young 182 children (1-5 years), $15-60 \%$ in school age children (6-19 years), 30- 60\% in adults, and 183 more than $85 \%$ in the older population [Heegaard et al., 2002]. B19V is thought to be a "hit 184 and run" virus which can be eliminated completely. However, it was reported that B19V 185 may persist in the bone marrow [Cassinotti et al., 1997; Heegaard et al., 2002; Lundqvist et 186 al., 1999a; Lundqvist et al., 1999b], muscle [Chevrel et al., 2000], synovia [Nikkari et al., 187 1995] and the skin [Vuorinen et al., 2002] in immunocompetent individuals with the 188 absence of viremia or symptomatic infection. Likewise, three groups of investigation 189 demonstrated the persistence of B19V DNA in the liver [Abe et al., 2007; Eis-Hubinger et 190 al., 2001; Wong et al., 2003]. Strong additional evidence is provided that B19V may indeed 191 persist in the liver as B19V DNA was detectable in more than half of the snap frozen liver 192 tissues investigated.

193 Whether B19V is a pathogenic agent of fulminant liver failure and non-A-E hepatitis or a 194 major risk factor to worsen liver function and accelerate disease progression is still 195 controversial. One study from China suggested that the co-infection of B19V and HBV did 196 not lead to more severe liver damage [He et al., 2003]. Nevertheless, two other studies on 197 B19V infection in patients with chronic viral hepatitis led to different conclusions. Hsu et al. 198 [2005] detected B19V DNA in serum samples from patients in Taiwan infected with HBV 199 (37\%) and patients infected with HCV (24\%) by nPCR. Furthermore, IgM antibodies were 200 detected in patients with HBV (35\%) and HCV (16\%). However, co-infection of B19V with $201 \mathrm{HBV}$ or HCV did not increase the frequency of liver dysfunction in patients with chronic 202 hepatitis. In contrast, Toan et al. [2006] demonstrated that the persistent B19V infection was 
not only frequent in Vietnamese patients with HBV but also associated with severe hepatitis

B-associated liver disease.

In order to find out whether B19V acts indeed as a bystander or a participator in the progression of liver disease, the prevalence of $\mathrm{B} 19 \mathrm{~V}$ infection in patients with chronic hepatitis C and B as well as healthy individuals in Germany were assessed. The frequency

208 of serologically recovered was not different in patients infected with HCV than in healthy 209 individuals and coincided with the average level reported previously [Young and Brown, 210 2004]. Past B19V infection had also no apparent impact on biochemical and histological 211 parameters of liver disease in patients with HCV. These findings suggest that B19V does 212 neither worsen liver disease nor accelerate disease progression in patients with chronic 213 hepatitis $\mathrm{C}$ in central Europe, however, larger studies are needed to confirm these results.

214 The frequency of B19V viremia was much lower in this study than in several reports 215 studying Asian cohorts of patients with liver disease (e.g. [Toan et al., 2006]). There is no 216 evidence that a technical problem to amplify B19V DNA was responsible for the low 217 frequency of B19V DNA in this study. First, the positive control worked always well and 218 secondly, the technique applied was able to detect B19V DNA at high frequencies in liver 219 tissue samples. Therefore, the most likely explanation for different results of different 220 studies is that B19V viremia is more frequent in East-Asia than in Germany. Further studies 221 on additional cohorts in Europe and other regions of the world need to clarify this issue.

222 In sharp contrast to biopsy samples, B19V DNA was found in more than half of the 223 explanted liver tissues studied. Interestingly B19V DNA was found more frequently in 224 end-stage liver tissues than in routine biopsy samples. However, there was no significant 225 difference in virus copy number per cell between these two groups. The presence of B19V 226 DNA in explanted liver tissues with different types of liver disease has been reported 227 previously ranging from 24\%-66\% [Abe et al., 2007; Eis-Hubinger et al., 2001; Langnas et 
228 al., 1995; Wong et al., 2003]. Eis-Huebinger et al [2001] also demonstrated that B19V DNA

229 can be found frequently in livers of adults with severe liver damage. In this study, the

230 frequency of B19V DNA in explanted liver was slightly higher than in previous studies.

231 This is the first study reporting the persistence of B19V DNA in routine biopsy liver

232 samples. However, whether the detection of B19V DNA is the cause or consequence of

233 progressive liver disease is unknown. Only a prospective study comparing the outcome of

234 liver disease in individuals with detectable and undetectable B19V DNA in liver biopsies

235 would be able to answer this question.

236 The only patient with detectable viremia for more than one year had no B19V-related

237 symptoms. Prolonged B19V infection seems to be not rare as clearance of B19V viremia

238 has been reported to be more slowly than previously considered, despite early resolution of

239 symptoms [Lindblom et al., 2005]. Thus this case would be in line with this report.

240 Importantly, the patient showed persistent viremia despite parallel treatment with high doses

241 of interferon alpha-2b and ribavirin. Whether the second course of antiviral therapy with

242 pegylated interferon alpha- $2 \mathrm{~b}$ and ribavirin has contributed to the clearance of $\mathrm{B} 19 \mathrm{~V}$

243 viremia remains speculative. In this respect it is worthy to note that treatment trials for

244 B19V-myocarditis with interferon beta are ongoing [Kuhl, 2005].

245 Persistence of B19V DNA detection is usually associated with B19V DNA detection in

246 biopsy specimens in the absence of detectable B19V DNA in sera or plasma [Norja et al.,

247 2008]. The finding of B19V DNA detection in the liver but not in sera is therefore in line

248 with previous studies. It also has to be considered that B19V genotype 1 is almost

249 exclusively found in Western Europe while genotype 2 is frequent in Asia. This may also

250 account for some differences. The previous study by Toan et al. [2006] studying B19V in

251 hepatitis B patients did not investigate B19V DNA in livers, however, other reports from 
252 Asia detected viral DNA in liver tissues from patients with fulminant hepatitis and biliary 253 atresia [Abe et al., 2007].

254 B19V specific $\mathrm{CD}^{+} \mathrm{T}$ cell responses have been first described in 1996 using 255 recombinant protein in $\operatorname{IgG}$ positive but $\operatorname{IgM}$ negative individuals [von Poblotzki et al., 256 1996]. Thereafter, several studies [Franssila et al., 2001; Mitchell et al., 2001; von Poblotzki 257 et al., 1996] reported that in serologically recovered individuals VP1, VP2, VP1/2 and VP1u 258 were major targets of $\mathrm{CD}^{+} \mathrm{T}$ cells. In 2006, Kasprowicz et al [2006] characterized B19V $259 \mathrm{CD}^{+} \mathrm{T}$ cell epitopes using overlapping peptides. In this study, two key immunodominant 260 peptides were employed to investigate $\mathrm{T}$ cell proliferation on a single-cell basis sensitive 261 flow cytometry-based CFSE-assay. Few positive responses were detected in patients with 262 chronic hepatitis C and healthy individuals who carried anti-B19V IgG antibody at the same 263 frequency and strength. Thus this study did not reveal an impairment of recall $\mathrm{T}$ cell 264 responses to another pathogen in patients with $\mathrm{HCV}$. This finding is of importance as $\mathrm{HCV}$ 265 may alter the function of several immune cells including dendritic cells [Bain et al., 2001; 266 Rehermann and Nascimbeni, 2005]. The normal T cell response to B19V is also in line with 267 the clinical finding that in patients with HCV infection the frequency of B19V viremia was 268 not increased, thus the low level of persisting intrahepatic B19V is controlled by intact 269 immunological mechanisms. Future studies will also need to investigate if B19V-specific T 270 cell responses are associated with severity of liver disease. In addition, studying intrahepatic 271 B19V-specific T cell responses might of interest.

$272 \mathrm{HCV}$-specific $\mathrm{CD}^{+} \mathrm{T}$ cell responses against recombinant $\mathrm{HCV}$ protein NS3, NS4 and 273 core were detectable in $2 / 13,5 / 13$ and $0 / 13$ patients with chronic hepatitis $\mathrm{C}$ who infected 274 with serologically recovered B19V infection, respectively. This frequency of HCV-specific $275 \mathrm{CD}^{+} \mathrm{T}$ cell response was similar to most previous studies on patients with chronic hepatitis 276 C before therapy [Wedemeyer et al., 2002; Aberle et al., 2007] but lower than in patients 
277 after spontaneous HCV clearance [Meyer et al., 2007]. Thus, memory to B19V had no

278 apparent influence on $\mathrm{T}$ cell responses to $\mathrm{HCV}$ proteins in this study. However, future

279 studies will have to investigate potential cross-reactivities between B19V and HCV in more

280 detail and specifically also for $\mathrm{CD}^{+} \mathrm{T}$ cells.

281 In summary, B19V DNA may persist in the liver at a low level for a long period after

282 acute infection. However, even though B19V DNA can be detected intrahepatically, there is

283 no evidence that B19V is a "hepatitis virus" worsening liver disease and accelerating

284 disease progression of chronic hepatitis C in European patients. T cell responses to B19V

285 are also not affected by $\mathrm{HCV}$ infection suggesting that persisting B19V can well be

286 controlled by the host's immune system.

287

288

289 Acknowledgements: We are grateful to Ms. Heike Kaiser for her excellence assistance.

290 This work was supported by the Deutsche Forschungsgemeinschaft SFB-Transregio 19, TP

291 B5, by a grant from the German Network of Competence on Viral Hepatitis to HW (projects

292 10.2.2 and 10.2.4), the DFG Center grant SFB 738, project B2 and the IFB-Tx of Hannover

293 Medical School. 
Abe K, Kiuchi T, Tanaka K, Edamoto Y, Aiba N, Sata T. 2007. Characterization of erythrovirus B19 genomes isolated in liver tissues from patients with fulminant hepatitis and biliary atresia who underwent liver transplantation. Int J Med Sci 4(2):105-109.

Aberle JH, Perstinger G, Weseslindtner L, Sinzinger U, Gurguta C, Steindl-Munda P, Kundi M, Popow-Kraupp T, Ferenci P, Holzmann H. 2007. CD4+ T cell responses in patients with chronic hepatitis $\mathrm{C}$ undergoing peginterferon/ribavirin therapy correlate with faster, but not sustained, viral clearance. J Infect Dis 195(9):1315-1319.

Anderson MJ, Higgins PG, Davis LR, Willman JS, Jones SE, Kidd IM, Pattison JR, Tyrrell DA. 1985. Experimental parvoviral infection in humans. J Infect Dis 152(2):257-265.

Anderson MJ, Jones SE, Fisher-Hoch SP, Lewis E, Hall SM, Bartlett CL, Cohen BJ, Mortimer PP, Pereira MS. 1983. Human parvovirus, the cause of erythema infectiosum (fifth disease)? Lancet 1(8338):1378.

Bain C, Fatmi A, Zoulim F, Zarski JP, Trepo C, Inchauspe G. 2001. Impaired allostimulatory function of dendritic cells in chronic hepatitis C infection. Gastroenterology 120(2):512-524.

Cassinotti P, Burtonboy G, Fopp M, Siegl G. 1997. Evidence for persistence of human parvovirus B19 DNA in bone marrow. J Med Virol 53(3):229-232.

Chevrel G, Calvet A, Belin V, Miossec P. 2000. Dermatomyositis associated with the presence of parvovirus B19 DNA in muscle. Rheumatology (Oxford) 39(9):1037-1039.

Cossart YE, Field AM, Cant B, Widdows D. 1975. Parvovirus-like particles in human sera. Lancet 1(7898):72-73.

Crawford MP, Yan SX, Ortega SB, Mehta RS, Hewitt RE, Price DA, Stastny P, Douek DC, Koup RA, Racke MK, Karandikar NJ. 2004. High prevalence of autoreactive, neuroantigen-specific CD8+ T cells in multiple sclerosis revealed by novel flow cytometric assay. Blood 103(11):4222-4231.

Drago F, Semino M, Rampini P, Rebora A. 1999. Parvovirus B19 infection associated with acute hepatitis and a purpuric exanthem. Br J Dermatol 141(1):160-161.

Eis-Hubinger AM, Reber U, Abdul-Nour T, Glatzel U, Lauschke H, Putz U. 2001. Evidence for persistence of parvovirus B19 DNA in livers of adults. J Med Virol 65(2):395-401.

Franssila R, Hokynar K, Hedman K. 2001. T helper cell-mediated in vitro responses of recently and remotely infected subjects to a candidate recombinant vaccine for human parvovirus b19. J Infect Dis 183(5):805-809.

Gan YJ, Razzouk BI, Su T, Sixbey JW. 2002. A defective, rearranged Epstein-Barr virus genome in EBER-negative and EBER-positive Hodgkin's disease. Am J Pathol 160(3):781-786.

He Z, Zhuang H, Wang X, Song S, Dong Q, Yan J, Buehring GC, Luo G. 2003. Retrospective analysis of non-A-E hepatitis: possible role of hepatitis B and C virus infection. J Med Virol 69(1):59-65.

Heegaard ED, Petersen BL, Heilmann CJ, Hornsleth A. 2002. Prevalence of parvovirus B19 and parvovirus V9 DNA and antibodies in paired bone marrow and serum samples from healthy individuals. J Clin Microbiol 40(3):933-936.

Hillingso JG, Jensen IP, Tom-Petersen L. 1998. Parvovirus B19 and acute hepatitis in adults. Lancet 351(9107):955-956.

Hsu TC, Chen TY, Lin MC, Tzang BS, Tsay GJ. 2005. Human parvovirus B19 infection in patients with chronic hepatitis B or hepatitis C infection. J Gastroenterol Hepatol 20(5):733-738.

Karetnyi YV, Beck PR, Markin RS, Langnas AN, Naides SJ. 1999. Human parvovirus B19 infection in acute fulminant liver failure. Arch Virol 144(9):1713-1724.

Kasprowicz V, Isa A, Tolfvenstam T, Jeffery K, Bowness P, Klenerman P. 2006. Tracking of peptide-specific CD4+ T-cell responses after an acute resolving viral infection: a study of parvovirus B19. J Virol 80(22):11209-11217.

Kuhl U. 2005. Antiviral treatment of myocarditis and acute dilated cardiomyopathy. Heart Fail Clin 1(3):467-474.

Langnas AN, Markin RS, Cattral MS, Naides SJ. 1995. Parvovirus B19 as a possible causative agent of fulminant liver failure and associated aplastic anemia. Hepatology 22(6):1661-1665.

Lehmann U, Wingen LU, Brakensiek K, Wedemeyer H, Becker T, Heim A, Metzig K, Hasemeier B, Kreipe H, Flemming P. 2007. Epigenetic defects of hepatocellular carcinoma are already found in non-neoplastic liver cells from patients with hereditary haemochromatosis. Hum Mol Genet 16(11):1335-1342.

Lindblom A, Isa A, Norbeck O, Wolf S, Johansson B, Broliden K, Tolfvenstam T. 2005. Slow clearance of human parvovirus B19 viremia following acute infection. Clin Infect Dis 41(8):1201-1203. 
Lundqvist A, Tolfvenstam T, Bostic J, Soderlund M, Broliden K. 1999a. Clinical and laboratory findings in immunocompetent patients with persistent parvovirus B19 DNA in bone marrow. Scand J Infect Dis 31(1):11-16.

Lundqvist A, Tolfvenstam T, Brytting M, Stolt CM, Hedman K, Broliden K. 1999b. Prevalence of parvovirus B19 DNA in bone marrow of patients with haematological disorders. Scand J Infect Dis 31(2):119-122.

Manns MP, Wedemeyer H, Cornberg M. 2006. Treating viral hepatitis C: efficacy, side effects, and complications. Gut 55(9):1350-1359.

Meyer MF, Lehmann M, Cornberg M, Wiegand J, Manns MP, Klade C, Wedemeyer H. 2007. Clearance of low levels of HCV viremia in the absence of a strong adaptive immune response. Virol J 4:58.

Mitchell LA, Leong R, Rosenke KA. 2001. Lymphocyte recognition of human parvovirus B19 non-structural (NS1) protein: associations with occurrence of acute and chronic arthropathy? J Med Microbiol 50(7):627-635.

Nikkari S, Roivainen A, Hannonen P, Mottonen T, Luukkainen R, Yli-Jama T, Toivanen P. 1995. Persistence of parvovirus B19 in synovial fluid and bone marrow. Ann Rheum Dis 54(7):597-600.

Norja P, Eis-Hubinger AM, Soderlund-Venermo M, Hedman K, Simmonds P. 2008. Rapid sequence change and geographical spread of human parvovirus B19: comparison of B19 virus evolution in acute and persistent infections. J Virol 82(13):6427-6433.

Rehermann B, Nascimbeni M. 2005. Immunology of hepatitis B virus and hepatitis C virus infection. Nat Rev Immunol 5(3):215-229.

Semmo N, Krashias G, Willberg C, Klenerman P. 2007. Analysis of the relationship between cytokine secretion and proliferative capacity in hepatitis C virus infection. J Viral Hepat 14(7):492-502.

So K, Macquillan G, Garas G, Delriviere L, Mitchell A, Speers D, Mews C, Augustson B, de Boer WB, Baker D, Jeffrey GP. 2007. Urgent liver transplantation for acute liver failure due to parvovirus B19 infection complicated by primary Epstein-Barr virus and cytomegalovirus infections and aplastic anaemia. Intern Med J 37(3):192-195.

Sokal EM, Melchior M, Cornu C, Vandenbroucke AT, Buts JP, Cohen BJ, Burtonboy G. 1998. Acute parvovirus B19 infection associated with fulminant hepatitis of favourable prognosis in young children. Lancet 352(9142):1739-1741.

Suneetha PV, Schlaphoff V, Wang C, Stegmann KA, Fytili P, Sarin SK, Manns MP, Cornberg M, Wedemeyer H. 2009. Effect of peptide pools on effector functions of antigen-specific CD8+ T cells. J Immunol Methods 342(1-2):33-48.

Toan NL, Song le H, Kremsner PG, Duy DN, Binh VQ, Duechting A, Kaiser H, Torresi J, Kandolf R, Bock CT. 2006. Co-infection of human parvovirus B19 in Vietnamese patients with hepatitis B virus infection. J Hepatol 45(3):361-369.

Urbani S, Amadei B, Fisicaro P, Pilli M, Missale G, Bertoletti A, Ferrari C. 2005. Heterologous T cell immunity in severe hepatitis C virus infection. J Exp Med 201(5):675-680.

von Poblotzki A, Gerdes C, Reischl U, Wolf H, Modrow S. 1996. Lymphoproliferative responses after infection with human parvovirus B19. J Virol 70(10):7327-7330.

Vuorinen T, Lammintausta K, Kotilainen P, Nikkari S. 2002. Presence of parvovirus B19 DNA in chronic urticaric and healthy human skin. J Clin Virol 25(2):217-221.

Wandinger K, Jabs W, Siekhaus A, Bubel S, Trillenberg P, Wagner H, Wessel K, Kirchner H, Hennig H. 2000. Association between clinical disease activity and Epstein-Barr virus reactivation in MS. Neurology 55(2):178-184.

Wedemeyer H, He XS, Nascimbeni M, Davis AR, Greenberg HB, Hoofnagle JH, Liang TJ, Alter H, Rehermann B. 2002. Impaired effector function of hepatitis C virus-specific CD8+ T cells in chronic hepatitis C virus infection. J Immunol 169(6):3447-3458.

Wedemeyer H, Mizukoshi E, Davis AR, Bennink JR, Rehermann B. 2001. Cross-reactivity between hepatitis C virus and Influenza A virus determinant-specific cytotoxic T cells. J Virol 75(23):11392-11400.

Welsh RM, Kim SK, Cornberg M, Clute SC, Selin LK, Naumov YN. 2006. The privacy of T cell memory to viruses. Curr Top Microbiol Immunol 311:117-153.

Wong S, Young NS, Brown KE. 2003. Prevalence of parvovirus B19 in liver tissue: no association with fulminant hepatitis or hepatitis-associated aplastic anemia. J Infect Dis 187(10):1581-1586.

Yoto Y, Kudoh T, Haseyama K, Suzuki N, Chiba S. 1996. Human parvovirus B19 infection associated with acute hepatitis. Lancet 347(9005):868-869.

Young NS, Brown KE. 2004. Parvovirus B19. N Engl J Med 350(6):586-597. 